\title{
Product Market Competition and Financial Flexibility: Evidence from China
}

\author{
Xinghe Liu' ${ }^{1}$ Ziyi Chen'1, Xinbao Yang2 \\ ${ }^{1}$ School of Accountancy, Guangdong University of Foreign Studies, Guangzhou, China \\ ${ }^{2}$ Ningbo Municipal Development \& Reform Commission, Ningbo, China \\ Email: xingheliu@126.com
}

How to cite this paper: Liu, X. H., Chen, Z. Y., \& Yang, X. B. (2020). Product Market Competition and Financial Flexibility: Evidence from China. Modern Economy, 11, 1401-1420.

https://doi.org/10.4236/me.2020.117099

Received: June 3, 2020

Accepted: July 24, 2020

Published: July 27, 2020

Copyright ( $) 2020$ by author(s) and Scientific Research Publishing Inc. This work is licensed under the Creative Commons Attribution International License (CC BY 4.0).

http://creativecommons.org/licenses/by/4.0/ (c) (i) Open Access

\begin{abstract}
This paper discusses the effects of product market competition on the value and level of corporate financial flexibility of Chinese listed firms for the period 2001-2014. We use three different measures of product market competition: predation risk, natural hedge and price-cost margin. Predation risk is used to measure how firms' growth opportunities covary with those of their industry rivals. We thus calculate the correlation of firm stock returns with industry stock returns. The regression coefficient on the industry return is then used as the proxy for predation risk. Greater values of this measure indicate a greater predation risk, more interdependence of investment opportunities and therefore fiercer competition. Natural hedge is calculated as the absolute value of the difference between a firm's ratio of net fixed assets per employee and the median ratio in the industry. To make this difference comparable across industries, the difference is then scaled by the industry range of the capital-to-labor ratio. Smaller values of this measure indicate greater similarity of a firm's operations with industry counterparts and therefore signal fierce competition. The results show that when the other conditions remain unchanged, the predation risk weakens the spare debt capacity and excessive cash holdings and ultimately decreases corporate financial flexibility. Except for the natural hedge used to measure the degree of product market competition, which does not significantly affect spare debt capacity, the other results show that natural hedge reduces excessive cash holdings and corporate financial flexibility. On the one hand, product market competition increases the demand for financing; because Chinese listed firms are subjected to China Securities Regulatory Commission (CSRC) supervision for issuing securities, they must increase debt and reduce their spare debt capacity. On the other hand, product market competition increases investment expenditure, consumes cash, and reduces excessive cash holdings. In the end, product market competition reduces corporate financial flexibility.
\end{abstract}




\section{Keywords}

Product Market Competition, Spare Debt Capacity, Excessive Cash Holdings

\section{Introduction}

Survey research shows that financial managers have regarded financial flexibility as the most important factor when making financing decisions (Graham \& Harvey, 2001; Bancel \& Mittoo 2004; Brounen et al., 2006). Despite general recognition of the importance of this flexibility, however, relevant studies are lacking, thus causing a mismatch between theory and practice. The corporate demand for financial flexibility comes from the imperfections of the real capital market. The Modigliani-Miller theorem, the footstone of modern capital structure theory, indicates that the internal and external capital of a company is interchangeable in the hypothesis of a perfect capital market. A company does not need to either reserve internal capital in case of need or maintain a low debt level to maintain its debt capacity. When internal capital is lacking, a company can easily raise money through external financing to meet unforeseen needs. In this case, the company is fully financially flexible. Conditions of the real capital market, however, differ considerably from those of a model. The capital market friction caused by such problems as information asymmetry and agency cost leads to imbalance between internal and external capital. A company cannot always find a solution when it urgently needs money, and in this sense, a company is not necessarily financially flexible. Current studies on financial flexibility focus mainly on its relation with financial decisions, especially its influence on investment (Arslan-Ayaydin et al., 2014; Zeng et al., 2013), financing (Clark, 2010) and dividend policies (Wang \& Zhang, 2012), regarding financial flexibility as an established fact, a driving factor that economically affects a company's financial policies. In contrast, few researchers have examined the factors relating to how financial flexibility changes.

In addition, a company does not operate in a vacuum; it is an entity whose operations and management are exercised in particular environments. Environments serve as the base and prerequisites of an operating company. Michael E. Porter, the well-known management expert, says in Competitive Strategy that what is most important for a company is having competitors in one or more industries. The industrial structure is so significant that it determines not only the competitive rules but also the potential corporate strategies. The importance of the external environment, however, is relative. There is universal recognition among academics regarding the far-reaching influence of competition on corporate financial policies. In the modern world, competition between companies is growing increasingly sharp, making it a priority for policy makers to consider. Reasonable decisions and improved competitiveness are possible only when the 
vast external environment of competition and the specific corporate conditions are examined together. This is the only way to gain competitive advantage and corporate value for a company that wants to rise to the occasion in the complex and changeable commercial environment.

Under the above background, this paper particularly addresses the effect of competition on financial flexibility from the perspective of industrial organization theory and the specific institutional circumstances in China. The changing process of financial flexibility and the ways and mechanism through which it is influenced by competition will be analyzed and discussed in this paper in order to expand the research scope of relevant studies and further explore strategic corporate financial theory.

The remainder of this paper is organized as follows. Section 2 outlines our theoretical analysis and research hypotheses. Section 3 introduces our methodology. Sections 4 and 5 present our empirical test and extensive tests, respectively. Section 6 is robust test. Section 7 concludes this paper.

\section{Theoretical Analysis and Research Hypotheses}

\subsection{Definition of Financial Flexibility}

Gamba and Triantis (2008) defined financial flexibility as “a company's capability to acquire and adjust its capital with low cost". Academics have not reached consensus about a precise measure of the existence and degree of a company's financial flexibility. The existing literature determines the existence of financial flexibility in three main ways: 1 ) a single measure (Arslan-Ayaydin et al., 2014; Zeng et al., 2013); 2) a combination of several measures (DeAngelo et al., 2011); and 3) the integration of several measures (Ma, 2010; Arslan-Ayaydin et al., 2014). Using a single measure such as cash holdings or debt capacity to analyze a company's financial flexibility is not consistent with its definition and fails to reveal its real state; a combination of several measures does not reveal insights into the particular financing channels and approaches despite its role in evaluating the differences in financing capacity and degree of financial flexibility among companies (Zeng et al. 2013). This paper references the studies of Zeng et al. and defines financial flexibility as the sum of excessive cash holdings and spare debt capacity. However, in this paper, the estimates of excessive cash holdings and spare debt capacity are based on a company's own characteristics rather than the average industry level.

\subsection{Mechanistic Analysis of the Influence of Competition on Financial Flexibility}

Competition influences financial flexibility through its impact on spare debt capacity and excessive cash holdings, as shown as Figure 1.

When confronted with stiff competition, financially powerful companies increase their production and lower prices to seize the market share, while those restricted by financing capabilities tend to withdraw from the market due to 


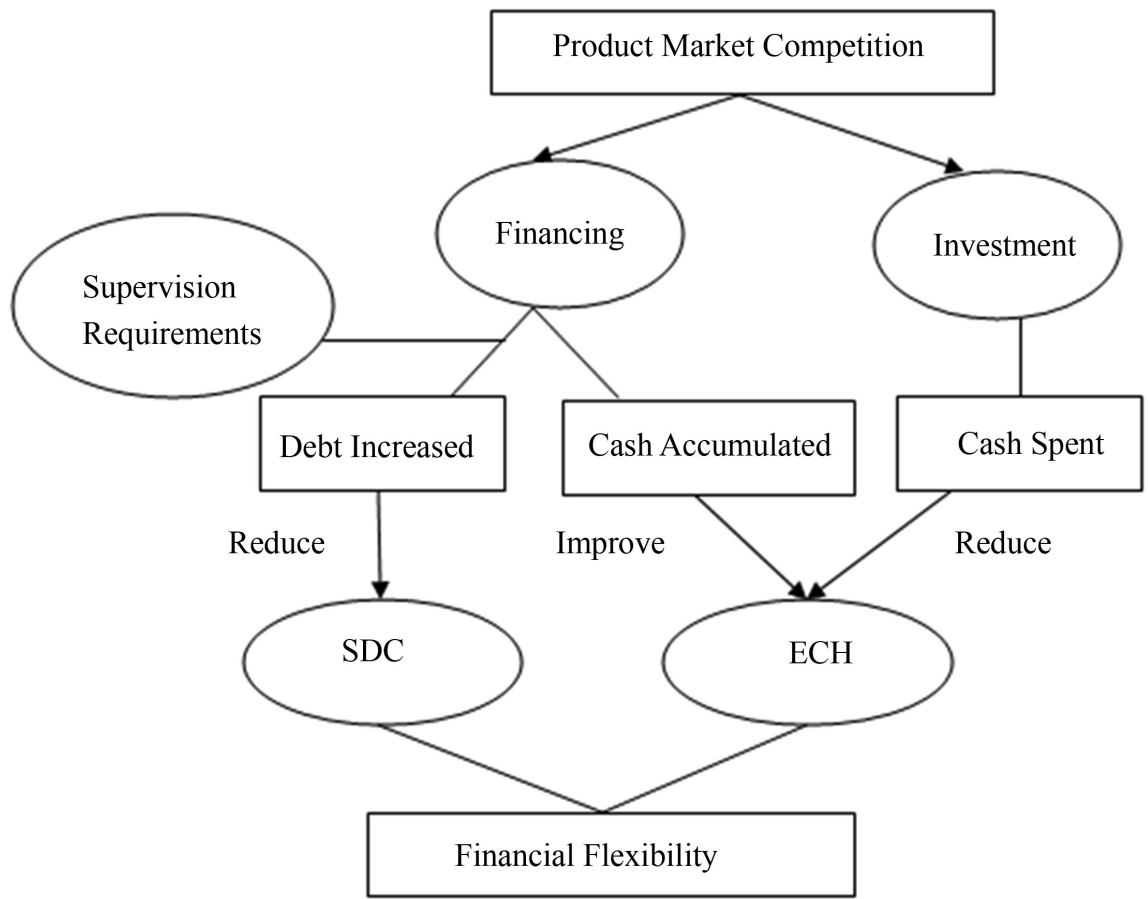

Figure 1. Mechanism of the influence of competition on financial flexibility.

finance problems (Bolton \& Scharfstein, 1990). Without capital support, a company cannot compete, as fierce competition will lower its market share and operational performance. Its financial flexibility is therefore threatened when money can only come from internal capital or be borrowed from the outside.

Securities issued in China comply with merit regulation. Provision 7 of Chapter 7 on opening issuing securities in Regulations for Issuing Securities of Chinese Listed Firms states that companies issuing stocks "must be able to make sustainable profit for at least three fiscal years". Moreover, Provision 8 requires these companies to be financially healthy, which means that "the profit accumulated in cash for the last three years should be no less than thirty percent of the annually average allocable profit made in the last three years". Requirements for openly raising equity for nonspecified objects seem stricter, a significant measure of which is the rate of return on common stockholders' equity, while companies that aim to increase the issuance should have an average weighted rate of return that is no less than $6 \%$. A prerequisite for listed firms to receive equity and finance is to meet the regulations of the China Securities Regulatory Commission (CSRC) concerning the net rate of return. Those requirements reduce the possibility of raising money in equity when companies in need of financing cannot easily qualify for refinancing if they have low rates of profit and cash flow and if they lag behind in profitability for three consecutive years and in rates of return and allocation of cash dividends. Allen et al. (2012) state that the equity financing market in China is still not comparable to bank credit in size and resource allocation despite its fast development. A financial system centering on 
bank credit also brings obstacles for equity financing. Many academics, such as Liu et al. (2003), Zhong and Fan (2004), and Min and Han (2008), show that most Chinese listed companies are facing fierce competition, and such competition is positively related to the capital structure. Strict regulation and a disadvantageous financing environment force companies to increase debt, and corporate financial flexibility decreases when their spare debt capacity is challenged in the face of competition.

$\mathrm{H}_{1}$ : When the other conditions remain unchanged, the fiercer the competition is, the lower the spare debt capacity will be.

There are uncertainties regarding the impact of competition on excessive cash holdings. Chevalier and Scharfstein (1995) show that financially strong companies can create more competitive edges through various approaches, including predatory pricing and strategic investment to improve the long-term performance of their products. In addition, the theoretical model of Benoi (1984) implies that cash holdings can be a competitive strategy to signal a threat to rivals and keep potential competitors from entering the market. Fresard (2010) empirically studied data from U.S.-listed companies and found that more cash holdings increase a company's future market share, which is more obvious when its competitors face more financing restrictions or the competition increases; in addition, the study shows that the competitive effect of cash helps increase a company's value and performance. According to the results of a study by Kim and Bettis (2014), the relation between Tobin's Q and cash holdings forms an inverted U-shaped quadratic function; i.e., Tobin's $\mathrm{Q}$ is related positively to cash holdings and negatively related to its square. Deb et al. (2017) determined that cash can create value for a company in an emergency and that the positive relation between cash and performance is clearer in companies with sharper competition, higher R \& D productivity and higher-growth industries and weaker in those with worse management, diversified operations and opaque information. Furthermore, Zhang and $\mathrm{Wu}$ (2012) found that excessive cash holdings have competitive effects, while Yang, Wu et al. (2015) tested the effect of corporate governance on cash holdings from the perspective of a mediating effect based on capital investment. Companies facing high competition tend to strategically increase cash holdings due to the competitive effect. For example, Hoberg et al. (2014) analyzed firms' product descriptions using computational linguistics and developed a new measure for product market threats-product market fluidity-which shows that more product market threats decrease "firm propensity to pay dividends and repurchase shares and increases the cash a firm holds". Morellec et al. (2014) empirically tested a dynamic cash management model and found that companies confronted with fierce competition increase their cash holdings and the possibility of stock issuance, especially companies restricted by small size and financing problems. Yang and Wang (2015) discovered that companies facing stiff competition show more cash-cash flow sensitivity; i.e., they internalize the cash flow generated by business operations in the form of 
cash or cash equivalents, and thus, they increase cash holdings to improve financial flexibility when they encounter sharp competition. Despite competition in price and production, however, a company must also strategically invest in capital input, $\mathrm{R} \& \mathrm{D}$, network layout, advertisement and publicity, recruitment, etc., to protect its market share from being deprived of or even ejected from the market and to get ahead of the curve. Therefore, cash holdings are consumed, resulting in reductions in excessive cash holdings and financial flexibility. According to the aforementioned issues, this paper proposes the following hypotheses:

$\mathrm{H}_{2 \mathrm{a}}$ : When the other conditions remain unchanged, the fiercer the competition is, the higher the excessive cash holdings will be.

$\mathrm{H}_{2 b}$ : When the other conditions remain unchanged, the fiercer the competition is, the lower the excessive cash holdings will be.

This paper has defined financial flexibility as the sum of spare debt capacity and excessive cash holdings. It has been found that competition can either increase corporate financial flexibility through cash accumulation or reduce it through extra debt and cash spent. On the one hand, competition generally reduces a company's spare debt capacity, but on the other hand, it may increase or reduce cash holdings. In this regard, competition can influence corporate financial flexibility in opposite ways, so we propose the following hypotheses:

$\mathrm{H}_{3 \mathrm{a}}$ : When the other conditions remain unchanged, the fiercer the competition is, the higher the overall financial flexibility will be.

$\mathrm{H}_{3 \mathrm{~b}}$ : When the other conditions remain unchanged, the fiercer the competition is, the lower the overall financial flexibility will be.

\section{Methodology}

\subsection{Samples}

To perform empirical analysis, we have chosen A-share listed companies for the period 2001-2014 that have met the following requirements: 1) They must be nonfinancial companies. 2) They must not have negative net assets (total assets minus cash holdings) and book stakeholders' equity. 3) They must not have negative revenue. 4) They must have an accounting index. 5) They must not be in an industry with fewer than 5 companies in the market. All required financial data and stock yield data are from Wind Info and the China Stock Market \& Accounting Research (CSMAR) Database. Finally, the above areas provide a total of 19038 available observations. We have winsorized all variables below $1 \%$ and above $99 \%$ to mitigate the effects of outliers by making variables below $1 \%$ equal to $1 \%$ and those above $99 \%$ equal to $99 \%$.

\subsection{Measure of Variables}

\subsubsection{Measure of Financial Flexibility}

We use the sum of excessive cash holdings and spare debt capacity to represent the overall financial flexibility. 
Measure of Excessive Cash Holdings. First, we use the influencing factors of cash holdings to estimate the optimal corporate cash holdings, which can be shown as the following regression Equation (1):

$$
\operatorname{Cash}_{i, t}=\alpha_{0}+\sum_{k} \alpha_{k} x_{k, i, t}+\mu_{i}+\theta_{t}+v_{i, t}
$$

where Cash stands for the sum of monetary capital and financial assets held or traded. According to Chen et al. (2012) and Megginson et al. (2014), x, the control variable for the corporate conditions, includes corporate size, tangible assets, debt level, cash flow, capital expenditure, net working capital, Tobin's Q, reform of nontradable shares, nature of property rights, etc.; $\alpha_{0}$ is the constant term; $\mu_{i}$ is the entity fixed effect, $\theta_{t}$ is the year fixed effect; and $v_{i, t}$ is the random disturbance term.

Next, we use the difference between the actual value and the fitted value to measure the deviation between actual cash holdings and optimal cash holdings. We then make a judgment based on the calculated residual. If it is greater than zero, then excessive cash holdings equal the residual; if not, then excessive cash holdings equal zero, which is

$$
\mathrm{ECH}=\max (0, v) .
$$

Measure of Spare Debt Capacity. The empirical equation of Frank and Goyal (2003) is our basic model here. With data for the corporate conditions, we estimate the optimal capital structure using a two-way fixed effects method for panel data. The fitted value of regression Equation (2) is used to measure the optimal capital structure.

$$
\operatorname{Lev}_{i, t}=\alpha_{0}+\sum_{k} \alpha_{k} x_{k, i, t}+\mu_{i}+\theta_{t}+v_{i, t}
$$

For bulleted lists, Lev stands for book leverage. The control variable $x$ includes the corporate size, tangible assets, profitability, growth opportunity, tax shield effect, industry median of the capital structure, etc.; $\alpha_{0}$ is the constant term; $\mu_{i}$ is the entity fixed effect; $\theta_{t}$ is the year fixed effect; and $v_{i, t}$ is the random disturbance term.

Next, we make a judgment based on the residual of Equation (2). If it is greater than zero, then the actual debt level exceeds the optimal debt level, and the spare debt capacity is zero. If not, then the actual debt level is lower than the optimal debt level, and we take the absolute value of the residual to be the proxy of the spare debt capacity, which is

$$
\mathrm{SDC}=|\min (0, v)| .
$$

Financial flexibility in this paper can therefore be quantified as follows:

$$
\mathrm{FF}=\mathrm{ECH}+\mathrm{SDC}
$$

\subsubsection{Measure of Product Competition}

Many academics have proposed measures for product competition in the market, and we considered this research in choosing the following measures for the 
level of product competition.

Predation Risk-The Industry Beta. We refer to Haushalter et al. (2007) and $\mathrm{Chi}$ and $\mathrm{Su}$ (2015) and use the industry beta to measure the interdependency of investment opportunities between a company and its rivals. Since stock price can reflect the present worth of future cash flow, rival companies will be more sensitive to a corporate stock price if the company shares more growth opportunities with its rivals. The industry beta indicates the sensitivity, which means that it increases with increasing interdependency between a company and its rivals and increasing predation risk and competition. This beta can be calculated as follows:

$$
r_{i, t}=\beta_{0}+\beta_{1} \cdot r_{\text {industry }, t}+\beta_{2} \cdot r_{m, t}+\varepsilon_{i, t}
$$

where $r_{i, t}$ is the monthly rate of return of dividend reinvestment considered by the sample company; $r_{\text {industry, }}$ is the average monthly yield ratio calculated according to the standard in Industry Classification Guidelines for Listed Companies issued by the CSRC in 2012; $r_{m, t}$ is the A-share monthly market yield ratio, i.e., the weighted average market value; and the sample estimates of the regression equation coefficients use rolling average data for the period of $36-60$ months. We use the estimated coefficient $\beta_{1}$ to measure the sensitivity of the individual share yield ratio to the industrial yield ratio. Higher $\beta_{1}$ values indicate stronger interdependencies, higher predation risk and sharper competition.

Similarities of Business Operations-Natural Hedge. Mackey and Philips (2005) and Yang et al. (2009) used the median capital-labor ratio in a certain industry in a certain year to represent the key technologies of the industry and calculated the gap between the capital-labor ratio of a company and the median capital-labor ratio of an industry, which is where the natural hedge comes from. It can be applied in measuring the gap in key technologies between a company and an industry, which can manifest in the level of similarities between business operations. The calculation of natural hedge $(\mathrm{NH})$ is as follows:

$$
\mathrm{NH}=\frac{\left|(K / L)_{f, i, y}-\operatorname{median}_{i, y,-f}(K / L)\right|}{\operatorname{range}\left\{\left|(K / L)_{f, i, y}-\operatorname{median}_{i, y,-f}(K / L)\right| \forall f \in i, y\right\}} \in[0,1]
$$

where $f$ represents the company, $i$ represents the industry, and $y$ represents the year. $K / \mathrm{L}$ is the capital-labor ratio, which is represented here by the net value of fixed assets/number of employees. The denominator range is calculated as follows: obtain the absolute value of the difference between the $K / L$ of a certain company in a certain industry and the industry median, calculate the range by subtracting the minimum from the maximum, and then divide the absolute value by the range. The result is the $\mathrm{NH}$ value. The lower the $\mathrm{NH}$ value is, the greater the business similarities and the sharper the competition. To increase clarity, we use the opposite of $\mathrm{NH}$ in the regression equation as the explanatory variable. 


\subsection{Empirical Model Specification}

To examine the relation between the product competition and spare debt capacity of a company, we performed multiple regression on the following empirical model:

$$
\mathrm{SDC}_{i, t}=\beta_{0}+\beta_{1} \cdot \mathrm{PMC}_{i, t}+Z \cdot X_{i, t}+\sum \text { Industry }+\sum \text { Year }+v_{i, t}
$$

To examine the relation between the product competition and excessive cash holdings of a company, we use the following empirical model:

$$
\mathrm{ECH}_{i, t}=\beta_{0}+\beta_{1} \cdot \mathrm{PMC}_{i, t}+Z \cdot X_{i, t}+\sum \text { Industry }+\sum \text { Year }+v_{i, t}
$$

To examine the relation between the product competition and overall financial flexibility of a company, we employ the following empirical model:

$$
\mathrm{FF}_{i, t}=\beta_{0}+\beta_{1} \cdot \mathrm{PMC}_{i, t}+Z \cdot X_{i, t}+\sum \text { Industry }+\sum \text { Year }+v_{i, t}
$$

where SDC is the spare debt capacity; ECH is the excessive cash holdings; FF is the corporate financial flexibility, i.e., the sum of excessive cash holdings and spare debt capacity; PMC is the proxy for product competition; and $X$ is the control variable including net trade credit, size, capex, Tobin's $Q$, cash flow, ownership concentration (first), and the proportion of state-owned property

\begin{tabular}{|c|c|c|}
\hline Variable & Definition & Calculation \\
\hline Cash & Cash holdings & Monetary capital + financial assets held for trading \\
\hline Lev & Leverage & Debt with interest/total assets \\
\hline $\mathrm{D}$ & Dividend & Dividend paid/total assets \\
\hline $\mathrm{ECH} 1$ & Excessive cash holdings & $\begin{array}{l}\text { The actual cash holdings of a company - the optimal cash } \\
\text { holdings estimated according to the conditions of a } \\
\text { company }\end{array}$ \\
\hline $\mathrm{ECH} 2$ & Excessive cash holdings & $\begin{array}{l}\text { Max }(0, \text { the actual cash holdings of a company - industry } \\
\text { average) }\end{array}$ \\
\hline SDC1 & Spare debt capacity & $\begin{array}{l}\text { The optimal debt estimated by corporate conditions - the } \\
\text { actual debt born by the company }\end{array}$ \\
\hline SDC2 & Spare debt capacity & $\begin{array}{l}\text { Max ( } 0 \text {, average debt of the industry - actual debt of the } \\
\text { company) }\end{array}$ \\
\hline FF1 & Financial flexibility & $\mathrm{FF} 1=\mathrm{ECH} 1+\mathrm{SDC} 1$ \\
\hline FF2 & Financial flexibility & $\mathrm{FF} 2=\mathrm{ECH} 2+\mathrm{SDC} 2$ \\
\hline Beta & Predation risk & $\begin{array}{l}\text { Regression coefficient of the individual yield to the industry } \\
\text { yield }\end{array}$ \\
\hline $\mathrm{NH}$ & Natural hedge & The capital-labor ratio adjusted by the industry \\
\hline$n$ & Number of companies & Number of listed companies per year \\
\hline Size & Company size & Natural logarithm of total assets \\
\hline NTC & Net trade credit & (The payable - the receivable)/sales revenue of that year \\
\hline Capex & Capital expenditure & $\begin{array}{l}\text { Cash paid to buy fixed assets, intangible assets and other } \\
\text { long-term assets/total assets }\end{array}$ \\
\hline
\end{tabular}
rights (state), state, etc. The specific calculation is shown in Table 1.

Table 1. Definition and calculation of the major variables. 


\section{Continued}

\begin{tabular}{|c|c|c|}
\hline Tobin's Q & Growth ability & $\begin{array}{l}\text { (Book value of the debt }+ \text { price per share } \times \text { number of the } \\
\text { outstanding shares }+ \text { net capital per share } \times \text { number of } \\
\text { nontradable shares)/total assets }\end{array}$ \\
\hline ROA & Return on assets & $\begin{array}{l}\text { Revenue before interest and after tax/total assets - the } \\
\text { industry average }\end{array}$ \\
\hline Cashflow & Net cash flow & Net cash generated by operations/total assets \\
\hline Inst & $\begin{array}{l}\text { Shareholding of } \\
\text { institutional investors }\end{array}$ & $\begin{array}{l}\text { Number of shares held by institutional investors/total } \\
\text { number of shares }\end{array}$ \\
\hline IPO & Initial public offering & The year of IPO equals 1: if not, it equals 0 \\
\hline State & $\begin{array}{l}\text { Proportion of state-owned } \\
\text { property rights }\end{array}$ & Number of state-owned shares/total number of shares \\
\hline
\end{tabular}

Source: integrated by the authors of this paper.

\section{Empirical Results}

\subsection{Descriptive Statistics for the Samples}

Table 2 presents the descriptive statistics for the major variables, indicating that the average levels of financial flexibility estimated by the corporate conditions and the industry average are 0.107 and 0.120 , respectively, which differ very little; however, the standard deviations are 0.125 and 0.156 , indicating a large gap in financial flexibility among the sample listed companies. The average industry beta is 1.024 , and the standard deviation is 0.608 , showing a significant difference in predation risk among Chinese listed companies. The average $\mathrm{NH}$ of 0.124 , the standard deviation of 0.212 and the median of 0.043 suggest that China has few capital-intensive listed companies such that the capital-labor ratios do not differ significantly. Each industry has an average of 83 listed companies $(\mathrm{n})$, and the standard deviation is 59 , indicating a wide difference among industries. The average net trade credit of the sample companies is -0.053 , and the median is -0.029 , showing little dependence on the trade credit of Chinese listed companies. The proportion of tangible assets is 0.432 , indicating that the sum of fixed assets and inventory constitutes a larger proportion of the total assets. A revenue ratio of 0.051 implies generally weak profitability for Chinese listed companies.

\subsection{Analysis of the Regression Results}

\subsubsection{The Two-Way Fixed Effects Method for Panel Data}

The influence of competition on a company's spare debt capacity, excessive cash holdings and financial flexibility is shown in Table 3. Models (1 - 3) take predation risk as the proxy for product competition, and the estimated coefficients of beta in the three models all appear negative under $10 \%$; thus, the higher the predation risk is, the lower the spare debt capacity, excessive cash holdings and financial flexibility. Models $(1-3)$ use similarities in operations as the proxy for product competition. Despite the opaque estimated coefficient of $\mathrm{NH}$ in Model (4), the coefficients of $\mathrm{NH}$ in both (5) and (6) appear positive under 5\%; hence, 
Table 2. Descriptive statistics for the major variables.

\begin{tabular}{|c|c|c|c|c|c|c|c|c|}
\hline Variables & Mean & SD & MIN & 25 th & Median & 75th & MAX & $\mathrm{N}$ \\
\hline $\mathrm{FF} 1$ & 0.107 & 0.124 & 0.000 & 0.000 & 0.066 & 0.171 & 0.814 & 19,038 \\
\hline FF2 & 0.120 & 0.156 & 0.000 & 0.000 & 0.055 & 0.185 & 1.226 & 19,038 \\
\hline $\mathrm{ECH} 1$ & 0.049 & 0.090 & 0.000 & 0.000 & 0.000 & 0.064 & 0.558 & 19,038 \\
\hline $\mathrm{ECH} 2$ & 0.061 & 0.103 & 0.000 & 0.000 & 0.000 & 0.083 & 0.896 & 19,038 \\
\hline SDC1 & 0.058 & 0.080 & 0.000 & 0.000 & 0.003 & 0.102 & 0.442 & 19,038 \\
\hline SDC2 & 0.059 & 0.086 & 0.000 & 0.000 & 0.000 & 0.104 & 0.505 & 19,038 \\
\hline Beta & 1.024 & 0.558 & -0.575 & 0.716 & 1.006 & 1.288 & 3.209 & 19,038 \\
\hline $\mathrm{NH}$ & 0.124 & 0.212 & 0.000 & 0.011 & 0.043 & 0.126 & 1.001 & 19,038 \\
\hline$N$ & 82.663 & 58.696 & 5 & 31 & 67 & 134 & 219 & 19,038 \\
\hline NTC & -0.053 & 0.409 & -2.069 & -0.181 & -0.029 & 0.094 & 1.544 & 18,925 \\
\hline Cash flow & 0.045 & 0.079 & -0.206 & 0.003 & 0.045 & 0.090 & 0.329 & 19,038 \\
\hline Capex & 0.060 & 0.058 & 0.000 & 0.017 & 0.043 & 0.084 & 0.296 & 19,038 \\
\hline Size & 21.595 & 1.171 & 18.329 & 20.776 & 21.446 & 22.236 & 25.267 & 19,038 \\
\hline Tang & 0.432 & 0.179 & 0.050 & 0.300 & 0.426 & 0.563 & 0.833 & 18,898 \\
\hline Q & 1.864 & 1.594 & 0.149 & 0.811 & 1.398 & 2.355 & 10.027 & 19,038 \\
\hline IPO & 0.048 & 0.215 & 0.000 & 0.000 & 0.000 & 0.000 & 1.000 & 19,038 \\
\hline Inst & 0.262 & 0.248 & 0.000 & 0.025 & 0.196 & 0.457 & 0.851 & 19,038 \\
\hline State & 0.179 & 0.241 & 0.000 & 0.000 & 0.000 & 0.377 & 0.922 & 19,038 \\
\hline
\end{tabular}

Source: integrated and calculated by the authors of this paper, the same as below.

Table 3. Product competition and financial flexibility.

\begin{tabular}{|c|c|c|c|c|c|c|}
\hline \multirow{2}{*}{$\begin{array}{l}\text { Independent variable } \\
\text { Dependent variable }\end{array}$} & \multicolumn{3}{|c|}{ Predation risk } & \multicolumn{3}{|c|}{ Similarities in operations } \\
\hline & SDC1 & $\mathrm{ECH} 1$ & FF1 & SDC1 & $\mathrm{ECH} 1$ & FF1 \\
\hline Model & (1) & (2) & (3) & (4) & (5) & (6) \\
\hline PMC & $\begin{array}{c}-0.002^{* * *} \\
(-2.47)\end{array}$ & $\begin{array}{l}-0.002^{*} \\
(-1.89)\end{array}$ & $\begin{array}{c}-0.004^{\star * *} \\
(-3.07)\end{array}$ & $\begin{array}{l}0.001 \\
(0.21)\end{array}$ & $\begin{array}{c}0.008^{\star * *} \\
(2.66)\end{array}$ & $\begin{array}{c}0.007^{\star *} \\
(2.04)\end{array}$ \\
\hline NTC & $\begin{array}{l}0.016^{\star * *} \\
(11.31)\end{array}$ & $\begin{array}{l}0.021^{\star * *} \\
(14.22)\end{array}$ & $\begin{array}{c}0.037^{\star * *} \\
(18.04)\end{array}$ & $\begin{array}{l}0.016^{\star \star \star} \\
(11.34)\end{array}$ & $\begin{array}{l}0.021^{\star * *} \\
(14.33)\end{array}$ & $\begin{array}{l}0.037^{\star * *} \\
(18.14)\end{array}$ \\
\hline Cash flow & $\begin{array}{c}0.053^{* * *} \\
(8.69)\end{array}$ & $\begin{array}{c}0.025^{\star * *} \\
(4.10)\end{array}$ & $\begin{array}{c}0.078^{\star * *} \\
(9.01)\end{array}$ & $\begin{array}{c}0.052^{\star * *} \\
(8.64)\end{array}$ & $\begin{array}{c}0.025^{\star * *} \\
(4.02)\end{array}$ & $\begin{array}{c}0.077^{\star * *} \\
(8.92)\end{array}$ \\
\hline Capex & $\begin{array}{c}-0.049^{* * *} \\
(-5.49)\end{array}$ & $\begin{array}{c}-0.131^{\star * *} \\
(-14.53)\end{array}$ & $\begin{array}{c}-0.180^{\star * *} \\
(-14.18)\end{array}$ & $\begin{array}{c}-0.049^{\star * *} \\
(-5.49)\end{array}$ & $\begin{array}{c}-0.132^{\star * *} \\
(-14.57)\end{array}$ & $\begin{array}{c}-0.181^{\star * *} \\
(-14.20)\end{array}$ \\
\hline Size & $\begin{array}{c}-0.006^{* * *} \\
(-6.25)\end{array}$ & $\begin{array}{c}-0.004^{* * *} \\
(-3.53)\end{array}$ & $\begin{array}{c}-0.010^{\star * *} \\
(-6.89)\end{array}$ & $\begin{array}{c}-0.006^{* * *} \\
(-6.26)\end{array}$ & $\begin{array}{c}-0.004^{* * *} \\
(-3.68)\end{array}$ & $\begin{array}{c}-0.010^{\star * *} \\
(-7.00)\end{array}$ \\
\hline Tang & $\begin{array}{c}-0.010^{* * *} \\
(-2.69)\end{array}$ & $\begin{array}{c}-0.187^{* * *} \\
(-47.32)\end{array}$ & $\begin{array}{c}-0.197^{\star * *} \\
(-35.50)\end{array}$ & $\begin{array}{c}-0.011^{\star * *} \\
(-2.72)\end{array}$ & $\begin{array}{c}-0.188^{\star * *} \\
(-47.31)\end{array}$ & $\begin{array}{c}-0.199^{\star * *} \\
(-35.51)\end{array}$ \\
\hline Tobin's Q & $\begin{array}{c}-0.004^{* * *} \\
(-8.10)\end{array}$ & $\begin{array}{c}-0.002^{\star * *} \\
(-3.79)\end{array}$ & $\begin{array}{c}-0.006^{* * *} \\
(-8.38)\end{array}$ & $\begin{array}{c}-0.004^{\star * *} \\
(-8.12)\end{array}$ & $\begin{array}{c}-0.002^{\star * *} \\
(-3.81)\end{array}$ & $\begin{array}{c}-0.006^{\star * *} \\
(-8.41)\end{array}$ \\
\hline IPO & $\begin{array}{c}0.017^{\star * *} \\
(8.01)\end{array}$ & $\begin{array}{l}0.102^{\star * *} \\
(47.10)\end{array}$ & $\begin{array}{l}0.119^{\star * *} \\
(39.09)\end{array}$ & $\begin{array}{c}0.017^{\star \star *} \\
(7.85)\end{array}$ & $\begin{array}{l}0.102^{\star * *} \\
(47.08)\end{array}$ & $\begin{array}{c}0.119^{* * *} \\
(38.95)\end{array}$ \\
\hline
\end{tabular}




\section{Continued}

\begin{tabular}{|c|c|c|c|c|c|c|}
\hline Inst & $\begin{array}{c}-0.006^{*} \\
(-1.89)\end{array}$ & $\begin{array}{l}-0.000 \\
(-0.09)\end{array}$ & $\begin{array}{l}-0.006 \\
(-1.39)\end{array}$ & $\begin{array}{c}-0.005^{\star} \\
(-1.74)\end{array}$ & $\begin{array}{l}0.000 \\
(0.05)\end{array}$ & $\begin{array}{l}-0.005 \\
(-1.18)\end{array}$ \\
\hline State & $\begin{array}{c}0.020^{* * *} \\
(6.74)\end{array}$ & $\begin{array}{l}-0.001 \\
(-0.26)\end{array}$ & $\begin{array}{c}0.019^{* * *} \\
(4.51)\end{array}$ & $\begin{array}{c}0.020^{* * *} \\
(6.79)\end{array}$ & $\begin{array}{l}-0.001 \\
(-0.17)\end{array}$ & $\begin{array}{c}0.019^{* * *} \\
(4.64)\end{array}$ \\
\hline Fixed Effect & Yes & Yes & Yes & Yes & Yes & Yes \\
\hline Year Effect & Yes & Yes & Yes & Yes & Yes & Yes \\
\hline$N$ & 18,785 & 18,785 & 18,785 & 18,785 & 18,785 & 18,785 \\
\hline$R^{2}$ & 0.029 & 0.258 & 0.190 & 0.029 & 0.258 & 0.190 \\
\hline
\end{tabular}

Note: The $t$ values are in parentheses; ${ }^{* *},{ }^{* *}$ and ${ }^{*}$ refer to significance at the $1 \%, 5 \%$ and $10 \%$ levels.

the lower the $\mathrm{NH}$ value is, the greater the similarities and the lower the excessive cash holdings and financial flexibility. In general, when the other conditions remain unchanged, competition weakens the spare debt capacity and excessive cash holdings and ultimately decreases corporate financial flexibility.

The regression results for the other control variables highlight the role of net trade credit as an informal financing channel to replace corporate debt (Shi and Zhang, 2010), which can help reduce a company's dependence on debt financing and increase its financial flexibility. The greater the cash flow generated in operations, the more likely a company can accumulate cash, resulting in improved flexibility. Moreover, the greater the tangible assets are, the weaker the liquidity, which means that it is difficult to convert them into cash, resulting in lower flexibility. Increased capex consumes cash, so flexibility is reduced, whereas IPO brings money in, so flexibility is increased; state-owned Chinese listed companies may face "tender restrictions of the budget", making it easier for them to receive subsidies from the government, thus enhancing their flexibility.

\subsubsection{The Panel Tobit Model Approach}

Previous estimates have shown that corporate financial flexibility is not less than 0 , in which case the value will be limited if it is used as an explained variable. Econometrics calls this a "limited dependent variable" model. Deviation will result if we estimate by ordinary least squares. The panel Tobit model is therefore chosen to obtain the estimates, and the results are shown in Table 4. Apart from the opaque regression coefficients in Models (2) and (4), the coefficients of the other four models are all significant at 5\%. Estimates of the other control variables are similar to those in Table 3. In sum, competition weakens spare debt capacity and excessive cash holdings and ultimately decreases corporate financial flexibility.

\section{Extensive Test}

We have inferred that competition causes companies to invest, which reduces excessive cash holdings. Whether this actually occurs, therefore, is the key component of the mechanism. Because this question requires further empirical examination, 
Table 4. Product competition and financial flexibility based on the regression results of the panel Tobit model.

\begin{tabular}{|c|c|c|c|c|c|c|}
\hline \multirow{2}{*}{$\begin{array}{l}\text { Independent variable } \\
\text { Dependent variable }\end{array}$} & \multicolumn{3}{|c|}{ Predation risk } & \multicolumn{3}{|c|}{ Similarities in operations } \\
\hline & SDC1 & $\mathrm{ECH} 1$ & FF1 & SDC1 & $\mathrm{ECH} 1$ & FF1 \\
\hline Model & (1) & (2) & (3) & (4) & (5) & (6) \\
\hline PMC & $\begin{array}{c}-0.003^{\star \star *} \\
(-3.90)\end{array}$ & $\begin{array}{l}-0.000 \\
(-0.22)\end{array}$ & $\begin{array}{c}-0.004^{\star * *} \\
(-2.84)\end{array}$ & $\begin{array}{l}-0.002 \\
(-0.62)\end{array}$ & $\begin{array}{c}0.010^{* *} \\
(3.53)\end{array}$ & $\begin{array}{c}0.008^{\star *} \\
(2.12)\end{array}$ \\
\hline NTC & $\begin{array}{c}0.018^{\star * *} \\
(13.13)\end{array}$ & $\begin{array}{c}0.019^{* * *} \\
(13.91)\end{array}$ & $\begin{array}{c}0.037^{\star * *} \\
(19.00)\end{array}$ & $\begin{array}{c}0.018^{* * *} \\
(13.14)\end{array}$ & $\begin{array}{c}0.020^{* * *} \\
(14.05)\end{array}$ & $\begin{array}{c}0.038^{* * *} \\
(19.11)\end{array}$ \\
\hline Cash flow & $\begin{array}{c}0.061^{\star * *} \\
(10.27)\end{array}$ & $\begin{array}{c}0.029^{* * *} \\
(4.78)\end{array}$ & $\begin{array}{c}0.088^{\star * *} \\
(10.44)\end{array}$ & $\begin{array}{c}0.061^{\star * *} \\
(10.23)\end{array}$ & $\begin{array}{c}0.028^{* * *} \\
(4.71)\end{array}$ & $\begin{array}{c}0.088^{\star * *} \\
(10.36)\end{array}$ \\
\hline Capex & $\begin{array}{c}-0.065^{\star * *} \\
(-7.62)\end{array}$ & $\begin{array}{c}-0.128^{\star * *} \\
(-14.71)\end{array}$ & $\begin{array}{c}-0.192^{\star * *} \\
(-15.66)\end{array}$ & $\begin{array}{c}-0.065^{\star * \star} \\
(-7.60)\end{array}$ & $\begin{array}{c}-0.129^{\star * *} \\
(-14.79)\end{array}$ & $\begin{array}{c}-0.193^{\star * *} \\
(-15.71)\end{array}$ \\
\hline Size & $\begin{array}{l}0.001 \\
(0.99)\end{array}$ & $\begin{array}{c}-0.010^{\star * *} \\
(-11.04)\end{array}$ & $\begin{array}{c}-0.009^{* * *} \\
(-7.54)\end{array}$ & $\begin{array}{l}0.001 \\
(1.14)\end{array}$ & $\begin{array}{c}-0.010^{\star * *} \\
(-11.22)\end{array}$ & $\begin{array}{c}-0.010^{\star * *} \\
(-7.55)\end{array}$ \\
\hline Tang & $\begin{array}{c}-0.020^{\star * \star} \\
(-5.47)\end{array}$ & $\begin{array}{c}-0.203^{\star * \star} \\
(-54.85)\end{array}$ & $\begin{array}{c}-0.221^{* * *} \\
(-42.37)\end{array}$ & $\begin{array}{c}-0.020^{* * *} \\
(-5.37)\end{array}$ & $\begin{array}{c}-0.204^{\star * \star} \\
(-54.90)\end{array}$ & $\begin{array}{c}-0.222^{\star * *} \\
(-42.34)\end{array}$ \\
\hline Tobin's Q & $\begin{array}{c}-0.003^{\star * *} \\
(-6.21)\end{array}$ & $\begin{array}{c}-0.001^{\star *} \\
(-2.02)\end{array}$ & $\begin{array}{c}-0.004^{* * *} \\
(-6.01)\end{array}$ & $\begin{array}{c}-0.003^{* * *} \\
(-6.23)\end{array}$ & $\begin{array}{c}-0.001^{\star *} \\
(-2.05)\end{array}$ & $\begin{array}{c}-0.004^{* * *} \\
(-6.05)\end{array}$ \\
\hline IPO & $\begin{array}{c}0.017^{* * *} \\
(8.27)\end{array}$ & $\begin{array}{c}0.104^{\star * *} \\
(48.85)\end{array}$ & $\begin{array}{c}0.121^{\star * *} \\
(40.54)\end{array}$ & $\begin{array}{c}0.017^{* * *} \\
(8.01)\end{array}$ & $\begin{array}{c}0.103^{* * *} \\
(48.94)\end{array}$ & $\begin{array}{c}0.120^{\star * *} \\
(40.42)\end{array}$ \\
\hline Inst & $\begin{array}{l}-0.002 \\
(-0.81)\end{array}$ & $\begin{array}{c}-0.006^{\star *} \\
(-2.21)\end{array}$ & $\begin{array}{c}-0.009^{\star *} \\
(-2.15)\end{array}$ & $\begin{array}{l}-0.002 \\
(-0.56)\end{array}$ & $\begin{array}{c}-0.006^{\star *} \\
(-2.17)\end{array}$ & $\begin{array}{c}-0.008^{*} \\
(-1.94)\end{array}$ \\
\hline State & $\begin{array}{c}0.023^{\star * *} \\
(8.44)\end{array}$ & $\begin{array}{l}-0.002 \\
(-0.74)\end{array}$ & $\begin{array}{c}0.021^{\star \star \star} \\
(5.26)\end{array}$ & $\begin{array}{c}0.023^{* * *} \\
(8.48)\end{array}$ & $\begin{array}{l}-0.002 \\
(-0.66)\end{array}$ & $\begin{array}{c}0.021^{\star * *} \\
(5.35)\end{array}$ \\
\hline Year Effect & Yes & Yes & Yes & Yes & Yes & Yes \\
\hline$N$ & 18,785 & 18,785 & 18,785 & 18,785 & 18,785 & 18,785 \\
\hline Wald $x 2(n)$ & 616.21 & 7086.69 & 4656.75 & 600.93 & 7105.03 & 4652.85 \\
\hline Rho & 0.544 & 0.567 & 0.584 & 0.545 & 0.566 & 0.584 \\
\hline
\end{tabular}

Note: The $t$ values are in parentheses; ${ }^{* *},{ }^{* *}$ and ${ }^{*}$ refer to significance at the $1 \%, 5 \%$ and $10 \%$ levels.

we use the following model to analyze the relation between competition and investment:

$$
\mathrm{INV}_{i, t}=\beta_{0}+\beta_{1} \cdot \mathrm{PMC}_{i, t-1}+Z \cdot X_{i, t-1}+\sum \text { Industry }+\sum \text { Year }+v_{i, t} X
$$

where INV is the cash paid for fixed assets, intangible assets and other long-term assets divided by the total assets at the beginning of a fiscal year. PMC is the proxy for competition, which is beta or NH. The control variable $x$ includes Tobin's $Q$, size, cash flow, cash holdings, leverage, first, state-owned enterprises, etc.

Table 5 shows the relation between competition and investment. Model (1) takes predation risk as the proxy for competition, while Model (2) uses similarities in operations. The estimates in Table 5 indicate a positive estimated coefficient of the Model (1) beta, and it is significant at 1\%; thus, the higher the predation risk is, the greater the investment expenditure. The estimated coefficient of 
Table 5. Product competition and corporate investment.

\begin{tabular}{|c|c|c|}
\hline Independent variable & Predation risk & Similarities in operations \\
\hline Model & (1) & (2) \\
\hline PMC & $\begin{array}{c}0.003^{* * *} \\
(2.86)\end{array}$ & $\begin{array}{c}-0.009^{* * *} \\
(-2.68)\end{array}$ \\
\hline Tobin's Q & $\begin{array}{c}0.008^{* * *} \\
(8.32)\end{array}$ & $\begin{array}{c}0.002^{* * *} \\
(3.48)\end{array}$ \\
\hline Cashflow & $\begin{array}{c}0.029^{* * *} \\
(3.92)\end{array}$ & $\begin{array}{c}0.047^{* * *} \\
(6.38)\end{array}$ \\
\hline Size & $\begin{array}{c}-0.010^{* * *} \\
(-7.92)\end{array}$ & $\begin{array}{c}-0.016^{* * *} \\
(-12.37)\end{array}$ \\
\hline Tang & $\begin{array}{c}-0.080^{\star * *} \\
(-16.59)\end{array}$ & $\begin{array}{c}-0.079^{* * *} \\
(-15.83)\end{array}$ \\
\hline Cash holdings & $\begin{array}{c}0.041^{* * *} \\
(6.60)\end{array}$ & $\begin{array}{c}0.036^{* * *} \\
(5.71)\end{array}$ \\
\hline Lev & $\begin{array}{c}-0.053^{* * *} \\
(-10.25)\end{array}$ & $\begin{array}{c}-0.044^{\star * *} \\
(-8.48)\end{array}$ \\
\hline Inst & $\begin{array}{c}0.028^{\star * *} \\
(7.54)\end{array}$ & $\begin{array}{c}0.027^{\star * *} \\
(7.12)\end{array}$ \\
\hline State & $\begin{array}{c}0.010^{* * *} \\
(2.89)\end{array}$ & $\begin{array}{c}0.008^{* * *} \\
(2.38)\end{array}$ \\
\hline Fixed Effect & Yes & Yes \\
\hline Year Effect & Yes & Yes \\
\hline$N$ & 18243 & 18201 \\
\hline$R^{2}$ & 0.106 & 0.106 \\
\hline
\end{tabular}

Note: The $t$ values are in parentheses; ${ }^{* *},{ }^{* *}$ and ${ }^{*}$ refer to significance at the $1 \%, 5 \%$ and $10 \%$ levels.

Model (2) NH is negative and significant at $1 \%$, indicating that the more similarities there are, the greater the investment expenditure. The regression results for the other control variables show that investment expenditure is positively related to Tobin's $\mathrm{Q}$, net cash flow, cash holdings, institutional investors and the proportion of state-owned property rights, whereas it is negatively related to corporate size, tangible assets and the debt ratio. In short, when the other conditions remain unchanged, product competition increases a company's investment expenditure.

\section{Robustness Checks}

\section{Other Measures of Financial Flexibility}

In China, Zeng et al. $(2011 ; 2013)$ used the gap of cash holdings between a company and the industry average to measure a company's excessive cash holdings, which can be calculated as follows: corporate excessive cash holdings $=$ Max (0, the existing cash holdings of a company - the industry average). Zeng et al. (2011; 2013) and Zhang and Wang (2015) used the difference between a com- 
pany's debt levels and the industry average to measure the company's spare debt capacity, which can be calculated as follows: corporate spare debt capacity = Max ( 0 , the industry average debt - the corporate existing debt). To draw a more robust and reliable conclusion, we reference their calculations and calculate a company's excessive cash holdings and spare debt capacity based on the industry average cash holdings and debt to measure corporate financial flexibility. The regression results are shown in Table 6.

Models ( 1 - 3) use predation risk as the proxy for competition, whereas Models $(4-6)$ instead use similarities in operations. The estimates in Table 6 show a negative estimated coefficient of the Model (1) beta, and the result is significant at $1 \%$, which means that the higher the predation risk is, the weaker the spare debt capacity. The estimated coefficient of Model (2) beta is negative and significant at $1 \%$, indicating that the higher the predation risk is, the lower the excessive cash holdings. The estimated coefficient of Model (3) beta is negative and

Table 6. Product competition and financial flexibility.

\begin{tabular}{|c|c|c|c|c|c|c|}
\hline \multirow{2}{*}{$\begin{array}{l}\text { Independent variable } \\
\text { Dependent variable }\end{array}$} & \multicolumn{3}{|c|}{ Predation risk } & \multicolumn{3}{|c|}{ Similarities in operations } \\
\hline & $\mathrm{SDC} 2$ & $\mathrm{ECH} 2$ & FF1 & SDC2 & $\mathrm{ECH} 2$ & FF2 \\
\hline Model & (1) & (2) & (3) & (4) & (5) & (6) \\
\hline PMC & $\begin{array}{c}-0.003^{* * *} \\
(-3.76)\end{array}$ & $\begin{array}{c}-0.004^{* * *} \\
(-3.88)\end{array}$ & $\begin{array}{c}-0.008^{* * *} \\
(-4.99)\end{array}$ & $\begin{array}{l}0.004 \\
(1.42)\end{array}$ & $\begin{array}{c}0.007^{\star *} \\
(1.99)\end{array}$ & $\begin{array}{c}0.011^{\star *} \\
(2.25)\end{array}$ \\
\hline NTC & $\begin{array}{c}0.017^{* * *} \\
(11.04)\end{array}$ & $\begin{array}{l}0.038^{* * *} \\
(22.47)\end{array}$ & $\begin{array}{c}0.055^{* * *} \\
(22.23)\end{array}$ & $\begin{array}{c}0.017^{* * *} \\
(11.00)\end{array}$ & $\begin{array}{c}0.040^{* * *} \\
(23.27)\end{array}$ & $\begin{array}{c}0.057^{* * *} \\
(22.85)\end{array}$ \\
\hline Cash flow & $\begin{array}{c}0.070^{* * *} \\
(10.70)\end{array}$ & $\begin{array}{c}0.126^{* * *} \\
(17.44)\end{array}$ & $\begin{array}{c}0.196^{* * *} \\
(18.57)\end{array}$ & $\begin{array}{c}0.067^{* * *} \\
(10.32)\end{array}$ & $\begin{array}{c}0.126^{* * *} \\
(17.18)\end{array}$ & $\begin{array}{c}0.192^{* * *} \\
(18.22)\end{array}$ \\
\hline Capex & $\begin{array}{c}-0.043^{* * *} \\
(-4.41)\end{array}$ & $\begin{array}{l}-0.260^{* * *} \\
(-24.36)\end{array}$ & $\begin{array}{l}-0.302^{* * *} \\
(-19.41)\end{array}$ & $\begin{array}{c}-0.043^{* * *} \\
(-4.46)\end{array}$ & $\begin{array}{l}-0.283^{* * *} \\
(-26.30)\end{array}$ & $\begin{array}{l}-0.326^{\star * *} \\
(-20.93)\end{array}$ \\
\hline Size & $\begin{array}{l}-0.029^{* * *} \\
(-26.64)\end{array}$ & $\begin{array}{l}0.001 \\
(0.61)\end{array}$ & $\begin{array}{l}-0.029^{* * *} \\
(-16.10)\end{array}$ & $\begin{array}{l}-0.028^{* * *} \\
(-26.52)\end{array}$ & $\begin{array}{l}0.002 \\
(1.59)\end{array}$ & $\begin{array}{l}-0.027^{\star * *} \\
(-15.16)\end{array}$ \\
\hline Tang & $\begin{array}{l}-0.050^{* * *} \\
(-11.96)\end{array}$ & $\begin{array}{l}-0.259^{* * *} \\
(-55.57)\end{array}$ & $\begin{array}{l}-0.309^{* * *} \\
(-45.45)\end{array}$ & $\begin{array}{l}-0.052^{\star * *} \\
(-12.35)\end{array}$ & $\begin{array}{l}-0.272^{\star * *} \\
(-57.26)\end{array}$ & $\begin{array}{l}-0.324^{\star * *} \\
(-47.20)\end{array}$ \\
\hline Tobin's Q & $\begin{array}{c}0.007^{* * *} \\
(13.58)\end{array}$ & $\begin{array}{c}0.004^{* * *} \\
(7.90)\end{array}$ & $\begin{array}{c}0.011^{* * *} \\
(13.83)\end{array}$ & $\begin{array}{c}0.007^{* * *} \\
(15.51)\end{array}$ & $\begin{array}{c}0.004^{* * *} \\
(8.07)\end{array}$ & $\begin{array}{c}0.012^{* * *} \\
(15.10)\end{array}$ \\
\hline IPO & $\begin{array}{c}0.031^{* * *} \\
(13.33)\end{array}$ & $\begin{array}{c}0.120^{* * *} \\
(47.00)\end{array}$ & $\begin{array}{c}0.151^{* * *} \\
(40.43)\end{array}$ & $\begin{array}{c}0.028^{* * *} \\
(13.06)\end{array}$ & $\begin{array}{c}0.127^{* * *} \\
(52.92)\end{array}$ & $\begin{array}{c}0.155^{* * *} \\
(44.63)\end{array}$ \\
\hline Inst & $\begin{array}{l}-0.005^{*} \\
(-1.67)\end{array}$ & $\begin{array}{l}0.002 \\
(0.68)\end{array}$ & $\begin{array}{l}-0.003 \\
(-0.57)\end{array}$ & $\begin{array}{l}-0.004 \\
(-1.26)\end{array}$ & $\begin{array}{l}0.003 \\
(0.92)\end{array}$ & $\begin{array}{l}-0.001 \\
(-0.13)\end{array}$ \\
\hline State & $\begin{array}{c}0.015^{* * *} \\
(4.88)\end{array}$ & $\begin{array}{l}0.003 \\
(0.80)\end{array}$ & $\begin{array}{c}0.018^{* * *} \\
(3.57)\end{array}$ & $\begin{array}{c}0.016^{* * *} \\
(5.00)\end{array}$ & $\begin{array}{l}0.001 \\
(0.18)\end{array}$ & $\begin{array}{c}0.016^{* * *} \\
(3.19)\end{array}$ \\
\hline Fixed Effect & Yes & Yes & Yes & Yes & Yes & Yes \\
\hline Year Effect & Yes & Yes & Yes & Yes & Yes & Yes \\
\hline$N$ & 18845 & 18845 & 18845 & 19132 & 19132 & 19132 \\
\hline$R^{2}$ & 0.144 & 0.332 & 0.309 & 0.143 & 0.369 & 0.334 \\
\hline
\end{tabular}

Note: The $t$ values are in parentheses; ${ }^{* *},{ }^{* *}$ and ${ }^{*}$ refer to significance at the $1 \%, 5 \%$ and $10 \%$ levels. 
significant at $1 \%$, indicating that the higher the predation risk is, the lower the corporate flexibility. Despite an opaque estimated coefficient of Model (4) NH, the coefficients of both Model (5) and (6) $\mathrm{NH}$ are significantly positive at the $5 \%$ level. The lower the $\mathrm{NH}$ is, the greater the number of product similarities and the lower the excessive cash holdings and financial flexibility. In general, when the other conditions remain unchanged, competition weakens the spare debt capacity and excessive cash holdings of a company and ultimately decreases its financial flexibility. The estimates for the other control variables show similar results, although the symbol estimates of Tobin's Q differ from the symbols in Table 3.

\section{1) Measures of Product Competition}

The number of enterprises can be a close measure of product competition. Generally, the greater the number of product similarities in an industry, the greater the number will be if the market share remains fixed and, thus, the sharper the competition will be. We choose the number of listed companies in the same industry in the same year as our measure. Models (1 - 3) use spare debt capacity, excessive cash holdings and financial flexibility estimated in line with corporate conditions as the dependent variables, while Models (4 - 6) use spare debt capacity, excessive cash holdings and financial flexibility estimated based on the industry average. The regression results of Table 7 show that the regression coefficients of the number of enterprises are negative and significant at $1 \%$. Therefore, that the number of enterprises is negatively related to spare debt capacity, excessive cash holdings and financial flexibility.

Table 7. Number of enterprises and financial flexibility.

\begin{tabular}{|c|c|c|c|c|c|c|}
\hline \multirow{2}{*}{$\begin{array}{l}\text { Calculation basis } \\
\text { Dependent variable }\end{array}$} & \multicolumn{3}{|c|}{ On the corporate conditions } & \multicolumn{3}{|c|}{ On the industry average } \\
\hline & SDC1 & ECH1 & FF1 & SDC2 & ECH2 & FF2 \\
\hline Model & (1) & (2) & (3) & (4) & (5) & (6) \\
\hline $\log (n)$ & $\begin{array}{c}-0.012^{* * *} \\
(-4.65)\end{array}$ & $\begin{array}{l}-0.013^{*} \\
(-4.57)\end{array}$ & $\begin{array}{c}-0.025^{* * *} \\
(-6.50)\end{array}$ & $\begin{array}{c}-0.031^{\star * *} \\
(-10.92)\end{array}$ & $\begin{array}{c}-0.019^{* *} \\
(-5.82)\end{array}$ & $\begin{array}{c}-0.051^{* * *} \\
(-10.73)\end{array}$ \\
\hline NTC & $\begin{array}{c}0.015^{\star * *} \\
(10.39)\end{array}$ & $\begin{array}{c}0.022^{* * *} \\
(14.73)\end{array}$ & $\begin{array}{c}0.037^{* * *} \\
(17.78)\end{array}$ & $\begin{array}{c}0.015^{\star * *} \\
(9.59)\end{array}$ & $\begin{array}{c}0.039^{* * *} \\
(22.44)\end{array}$ & $\begin{array}{c}0.054^{* * *} \\
(21.44)\end{array}$ \\
\hline Cash flow & $\begin{array}{c}0.044^{\star * *} \\
(7.34)\end{array}$ & $\begin{array}{l}0.026^{\star * *} \\
(4.13)\end{array}$ & $\begin{array}{c}0.069^{* * *} \\
(8.06)\end{array}$ & $\begin{array}{c}0.067^{\star * *} \\
(10.47)\end{array}$ & $\begin{array}{c}0.126^{\star * *} \\
(17.33)\end{array}$ & $\begin{array}{l}0.194^{\star * *} \\
(18.44)\end{array}$ \\
\hline Capex & $\begin{array}{c}-0.052^{\star * *} \\
(-5.85)\end{array}$ & $\begin{array}{c}-0.153^{\star * *} \\
(-16.75)\end{array}$ & $\begin{array}{c}-0.204^{\star * *} \\
(-16.08)\end{array}$ & $\begin{array}{c}-0.044^{* * *} \\
(-4.61)\end{array}$ & $\begin{array}{c}-0.283^{* * *} \\
(-26.33)\end{array}$ & $\begin{array}{c}-0.327^{* * *} \\
(-21.09)\end{array}$ \\
\hline Size & $\begin{array}{c}-0.004^{\star * *} \\
(-4.08)\end{array}$ & $\begin{array}{c}-0.003^{* * *} \\
(-2.76)\end{array}$ & $\begin{array}{c}-0.007^{* * *} \\
(-4.81)\end{array}$ & $\begin{array}{c}-0.026^{\star * *} \\
(-26.89)\end{array}$ & $\begin{array}{l}0.002 \\
(1.57)\end{array}$ & $\begin{array}{c}-0.027^{* * *} \\
(-15.40)\end{array}$ \\
\hline Tang & $\begin{array}{c}-0.011^{* * *} \\
(-2.92)\end{array}$ & $\begin{array}{c}-0.198^{* * *} \\
(-49.73)\end{array}$ & $\begin{array}{c}-0.210^{* * *} \\
(-37.70)\end{array}$ & $\begin{array}{c}-0.052^{* * *} \\
(-12.49)\end{array}$ & $\begin{array}{c}-0.271^{* * *} \\
(-57.62)\end{array}$ & $\begin{array}{c}-0.323^{* * *} \\
(-47.63)\end{array}$ \\
\hline Tobin's Q & $\begin{array}{c}-0.002^{\star * *} \\
(-5.43)\end{array}$ & $\begin{array}{c}-0.002^{\star * *} \\
(-3.96)\end{array}$ & $\begin{array}{c}-0.004^{\star * *} \\
(-6.61)\end{array}$ & $\begin{array}{c}0.007^{\star * *} \\
(15.63)\end{array}$ & $\begin{array}{c}0.004^{* * *} \\
(8.15)\end{array}$ & $\begin{array}{c}0.012^{\star * *} \\
(15.24)\end{array}$ \\
\hline IPO & $\begin{array}{c}0.015^{\star * *} \\
(7.74)\end{array}$ & $\begin{array}{c}0.107^{* * *} \\
(52.40)\end{array}$ & $\begin{array}{c}0.122^{\star * *} \\
(42.96)\end{array}$ & $\begin{array}{c}0.026^{* \star *} \\
(12.41)\end{array}$ & $\begin{array}{c}0.126^{\star * *} \\
(52.71)\end{array}$ & $\begin{array}{c}0.153^{\star * *} \\
(44.18)\end{array}$ \\
\hline
\end{tabular}




\begin{tabular}{ccccccc} 
Continued & \multicolumn{7}{c}{} \\
\hline Inst & -0.004 & -0.001 & -0.004 & -0.005 & 0.003 & -0.002 \\
& $(-1.22)$ & $(-0.18)$ & $(-0.98)$ & $(-1.52)$ & $(0.74)$ & $(-0.41)$ \\
State & $0.020^{* * *}$ & -0.002 & $0.018^{* * *}$ & $0.016^{* * *}$ & 0.001 & $0.017^{* * *}$ \\
& $(6.92)$ & $(-0.81)$ & $(4.22)$ & $(5.23)$ & $(0.33)$ & $(3.43)$ \\
Fixed Effect & Yes & Yes & Yes & Yes & Yes & Yes \\
Year Effect & Yes & Yes & Yes & Yes & Yes & Yes \\
$N$ & 19196 & 19196 & 19196 & 19196 & 19196 & 19196 \\
$R^{2}$ & 0.025 & 0.296 & 0.217 & 0.148 & 0.371 & 0.339 \\
\hline
\end{tabular}

Note: The $t$ values are in parentheses; ${ }^{* *},{ }^{* *}$ and ${ }^{*}$ refer to significance at the $1 \%, 5 \%$ and $10 \%$ levels.

\section{2) The Panel Binary Selection Model}

We use a binary variable of 0 or 1 according to the level of flexibility. Specifically, we divide the samples based on the median annual financial flexibility. Samples whose flexibility exceeds the median are valued at 1 , which means that they have better financial flexibility, and firms with flexibility below the median are defined as having weaker flexibility. We then obtain the estimates by using a panel Probit model, and the results remain robust.

\section{3) Rank Regression}

We perform an integrated sample test with the help of rank regression as follows: We rank the annual beta values from large to small and then divide them into three groups with the smallest group valued at 1 , the second valued at 2 and the largest valued at 3 . Next, we subtract every group by 2 and then divide the result by 2 , so the values of beta in the three groups are $0,0.5$ and 1, respectively. Since a larger beta means higher predation risk and sharper competition, a value of 0 indicates little competition, 0.5 indicates medium competition, and 1 indicates the fiercest competition. When we reassess the samples with the level of $\mathrm{NH}$ and number of enterprises and conduct regression analysis, the results remain robust.

\section{Conclusion and Suggestions}

\subsection{Conclusion}

This paper examines the influence of product competition on corporate financial flexibility with Chinese listed companies of 2001-2014 as the samples and with predation risk and similarities in operations as the proxy measures constructed according to industrial organizational theory. The results show that when the other conditions remain unchanged, predation risk weakens spare debt capacity and excessive cash holdings and ultimately decreases corporate financial flexibility. Except for the natural hedge used to measure the degree of product market competition, which does not significantly affect spare debt capacity, the results show that natural hedge reduces excessive cash holdings and corporate financial flexibility. On the one hand, product market competition increases the demand for financing. Because Chinese listed firms are subjected to CSRC supervision 
for issuing securities, they must increase their debt and reduce spare debt capacity. On the other hand, product market competition increases investment expenditure, consumes cash, and reduces excessive cash holdings. In the end, product market competition reduces corporate financial flexibility.

The following findings of this study are notable: first, sufficient financial flexibility can help a company address disadvantageous exogenous events and seize good investment opportunities. Much attention should be devoted to improving financial flexibility in daily operations. A company needs cash from inside or outside when bad circumstances or opportunities arise. Since securities issued in China follow the merit regulation, companies must abide by Regulations for Issuing Securities of Chinese Listed Firms. The CSRC strictly supervises corporate external financing, which is even more difficult for listed companies facing stiff competition that have low profit margins themselves. Restricted by the high cost of external capital and limited resources, a company must rely on its own resources when it needs capital support. Such companies should strive to improve their asset utilization ratios and cash generation capabilities. Second, fierce competition increases expenditures or reduces revenue, thus causing a glide of cash flow and affecting the company's ability to internally accumulate cash. When competition calls for more investment, such companies must seek sources of external financing for help. The equity financing market in China is developing quickly, but its size and allocation function are still limited compared to those of bank credit. In addition, merit regulation for securities issued in China represents a large obstacle for most enterprises, as some of them achieve little profit in drastic market competition and can scarcely meet the CSRC requirements for equity refinancing. They want to accumulate capital on their own, but it is beyond their ability to do so; they want to depend on equity financing, but the circumstances do not allow for it. They must sacrifice their subsequent competitiveness and turn to debt financing to contend with their rivals, but their financial flexibility is consequently reduced. We suggest that the country should increase the pace of issuing securities in China, from implementing merit regulation to establishing a registration system and mitigating the financing difficulties of small and medium-sized enterprises. Lowered financing costs and improved financing efficiency can help marketize stock issuance and optimize the allocation role of the capital market.

\subsection{Suggestions}

This paper provides empirical evidence for understanding the causes of corporate financial flexibility in emerging economies. Under the realistic background of increasingly fierce market competition and shortening industry life cycle, enterprises should reduce the debt level properly, fully estimate the option value of residual debt-raising ability, and keep some financial flexibility. In addition, enterprises should strengthen information disclosure management, reduce the degree of Information asymmetry, improve financing channels. The government 
should also further improve the external financing environment, reduce the external financing constraints faced by enterprises, and improve the business environment for enterprises.

\subsection{Research Deficiency and Prospect}

First of all, this paper does not discuss the moderating effect of product market competition on financial flexibility from the perspective of firm Heterogeneity. Secondly, this paper has not considered the impact of economic environment changes on financial flexibility; thirdly, this paper has not further analyzed the economic consequences of product market competition. These are the future directions of financial flexibility research.

\section{Disclosure Statement}

No potential conflicts of interest are reported by the authors.

\section{Conflicts of Interest}

The authors declare no conflicts of interest regarding the publication of this paper.

\section{References}

Allen, F., Qian, J., Zhang, C., \& Zhao, M. (2012). China's Financial System: Opportunities and Challenges. NBER Working Paper No. 17828.

http://finance.wharton.upenn.edu/ allenf/download/Vita/china\%27s\%20financial\%20s ystem $\% 20$ oct 11.pdf https://doi.org/10.3386/w17828

Arslan-Ayaydin, Ö., Florackis, C., \& Ozkan, A. (2014). Financial Flexibility, Corporate Investment and Performance: Evidence from Financial Crises. Review of Quantitative Finance and Accounting, 42, 211-250. https://doi.org/10.1007/s11156-012-0340-x

Bancel, F., \& Mittoo, U. R. (2004). Cross-Country Determinants of Capital Structure Choice: A Survey of European Firms. Financial Management, 33, 103-132. https://doi.org/10.2139/ssrn.683111

Bolton, P., \& Scharfstein, D. S. (1990). A Theory of Predation Based on Agency Problems in Financial Contracting. The American Economic Review, 80, 93-106.

Brounen, D., De Jong, A., \& Koedijk, K. (2006). Capital Structure Policies in Europe: Survey Evidence. Journal of Banking and Finance, 30, 1409-1442.

https://doi.org/10.1016/j.jbankfin.2005.02.010

Clark, B. J. (2010). The Impact of Financial Flexibility on Capital Structure Decisions: Some Empirical Evidence. https://doi.org/10.2139/ssrn.1499497

DeAngelo, H., DeAngelo, L., \& Whited, T. M. (2011). Capital Structure Dynamics and Transitory Debt. Journal of Financial Economics, 99, 235-261. https://doi.org/10.1016/j.jfineco.2010.09.005

Deb, P., David, P., \& O’Brien, J. (2017). When Is Cash Good or Bad for Firm Performance? Strategic Management Journal, 38, 436-454. https://doi.org/10.1002/smj.2486

Frank, M. Z., \& Goyal, V. K. (2003). Testing the Pecking Order Theory of Capital Structure. Journal of Financial Economics, 67, 217-248. 
https://doi.org/10.1016/S0304-405X(02)00252-0

Fresard, L. (2010). Financial Strength and Product Market Behavior: The Real Effects of Corporate Cash Holdings. The Journal of Finance, 65, 1097-1122. https://doi.org/10.1111/j.1540-6261.2010.01562.x

Graham, J. R., \& Harvey, C. R. (2001). The Theory and Practice of Corporate Finance: Evidence from the Field. Journal of Financial Economics, 60, 187-243. https://doi.org/10.1016/S0304-405X(01)00044-7

Haushalter, D., Klasa, S., \& Maxwell, W. F. (2007). The Influence of Product Market Dynamics on a Firm's Cash Holdings and Hedging Behaviour. Journal of Financial Economics, 84, 797-825. https://doi.org/10.1016/j.jfineco.2006.05.007

Hoberg, G., Phillips, G., \& Prabhala, N. (2014). Product Market Threats, Payouts, and Financial Flexibility. The Journal of Finance, 69, 293-324. https://doi.org/10.1111/jofi.12050

Kim, C., \& Bettis, R. A. (2014). Cash Is Surprisingly Valuable as a Strategic Asset. Strategic Management Journal, 35, 2053-2063. https://doi.org/10.1002/smj.2205

Liu, Z., Jiang, F., \& Lu, E. (2003). Capital Structure and Competition in Product Market. Economic Research Journal, 49, 60-67.

Ma, C. (2010). Design and Empirical Analysis of Corporate Financial Flexibility Index. Systems Engineering, 28, 61-66.

Megginson, W. L., Ullah, B., \& Wei, Z. (2014). State Ownership, Soft-Budget Constraints, and Cash Holdings: Evidence from China's Privatized Firms. Journal of Banking and Finance, 48, 276-291. https://doi.org/10.1016/j.jbankfin.2014.06.011

Min, D., \& Han, L. (2008). Market Structure, Industry Life Cycle and Capital Structure-An Analysis Based on the Corporate Strategy and Financial Theory. Management World, 24, 82-89.

Morellec, E., Nikolov, B., \& Zucchi, F. (2014). Competition, Cash Holdings, and Financing Decisions. Swiss Finance Institute Research Paper No. 13-72.

Wang, Z., \& Zhang, W. (2012). Financial Flexibility, Refinancing Options and a Catering Strategy of Dividends. Management World, 28, 151-163.

Yang, X., \& Wang, Z. (2015). Product Market Competition and the Cash Flow Sensitivity of Cash. Economic Management, 37, 52-63.

Zeng, A., Fu, Y., \& Wei, Z. (2011). Impact of Financial Crisis, Financial Flexibility and Corporate Finance-Empirical Evidence from Chinese-Listed Companies. Journal of Financial Research, 32, 155-169.

Zeng, A., Zhang C., \& Wei, Z. (2013). Impact of Financial Crisis, Financial Flexibility and Corporate Investment-Empirical Evidence from Chinese-Listed Companies. Management World, 29, 107-120.

Zhang, H., \& Wu, Y. (2012). Excessive Cash Holdings and Product Competition Advantages-Empirical Evidence from Chinese-Listed Companies. Journal of Financial Research, 33, 183-195.

Zhang, W., \& Wang, Z. (2015). How Geography Influences Dividend Policy: "Substitute Model" or "Outcome Model”? Economic Research Journal, 61, 76-88.

Zhong, T., \& Fan, Y. (2004). Level of Product Market Competition and Choice of Financial Leverage in Listed Companies. Accounting Research, 25, 73-77. 